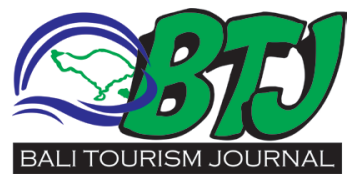

\section{Sanur Village Festival : The spirit of revival}

\author{
Anak Agung Gde Marvy Khrisna Pranamartha ${ }^{1}$
}

${ }^{1}$ Editor at Intisari Sains Medis (isainsmedis.id)

E-mail:agungmarvy@gmail.com

\section{Editor:}

Ida Bagus Ngurah Tri Pramana, Anak Agung Ngurah Yudistira Apriadi

Received: 28 July 2017 Accepted: 15 Aug 2017 Published: 13 September 2017

\title{
ABSTRACT
}

As a form of spirit to revive the economic stretch in Sanur after the First and second Bali Bombing Incidents, an event was established on 2006 known as Sanur Village Festival. Entering the year 2017, SVF activities always become one of tourism attractions for both local and foreign tourists. The festival consists of various contests and competitions, art and cultural attractions, music as well as different types of environmentally-friendly activities. SVF also fosters synergy among communities of citizens, governments and state-owned enterprises (BUMN) to encourage productivity of creative economy and stimulate creativity of young talents. Tourism Minister, Arief Yahya said the event is an example of tourism development with community-based and highly successful. According to him, this event could be imitated by other areas in developing tourism destinations with similar models.

Keyword: Sanur Village Festival, Tourism Development

Cite This Article: Anak Agung Gde Marvy Khrisna Pranamartha, Sanur Village Festival: The spirit of revival. Bali Tourism Journal (BTJ)2017, $1(1): 17-19$

\section{INTRODUCTION}

'Sanur', derived from two words; they are $S a$ meaning one, and Nur which means light of life. ${ }^{1}$ This traditional fisherman village was transformed into a famous tourist destination since the Grand Bali Beach Hotel was built in 1963 by President Sukarno. Tourism industry then becomes part of the livelihood of local residents there. However, when the first and second Bali Bombing Incidents occurred, tourism activities on the island of Bali had been paralyzed for several years. No exception in Sanur. As a form of spirit to revive the economic stretch in Sanur, as well as tourism promotion after bombing 1 and 2, an event was established. This event is known as Sanur Village Festival.

\section{THE EVENT}

Sanur village festival or often abbreviated as SVF, firstly launched in 2006. This community event founded by Yayasan Pembangunan Sanur (YPS) or Sanur Development Foundation. SVF is a combination of several large-scale activities involving food festival, creative economy exhibition, various contests and competitions, art and cultural attractions, music as well as different types of environmentally-friendly activities. ${ }^{2}$

Entering the year of 2017, SVF activities always become one of tourism attractions for both local and foreign tourists. The 2017 SVF was held at Maisonette Area, Inna Grand Bali Beach Bali, from 9 to 13 August 2017. ${ }^{3}$ Highlighting Bhinneka
Tunggal Ika; the spirit of unity in diversity as its theme (Figure 1). All programs are packaged in Indonesian ambiances and aim to embrace various components of society to celebrate the diversity of indonesia. Chairman of the Sanur Village Festival Committee, Ida Bagus Gede Sidharta mentioned that the theme of this year's activities is suitable and in accordance with the SVF's tagline, namely 'The New Spirit of Heritage'.

There are 27 agenda activities that can be enjoyed by tourists who come to Sanur. 27 Activities are Environment Activities, Clean Beach, Coral Plantation, baby turtle release to the Sea, Extinction Plantation and Festival Exhibition. In addition, there are also Sanur Kreatif Expo, Cultural, Music and Art Performances, Horticulture, Culinary, Food Festival, Food Heritage, Painting, Painting on the spot, Body Painting, Photography Competition, Photo Exhibition, Photography, Sports Activities, Fun Games, Fun Run, Golf Tournament, Jukung Race, Fishing Tournaments, Kids Zone and Village Cycling Tour.

A series of activities started with Sanur International Kite Festival, international kite competitions, from 3-6 August 2017. Then, on 4 to 19 August 2017 a photo exhibition was held at Griya Santrian Resort and Villa, titled 'Unity in Diversity'. The photo exhibition is piece of work by Bali photographers who have been through the selection stage and selected 34 photos for display. The 2017 SVF series will be closed with sport tourism activities of Bali International Triathlon 2017 on 15 


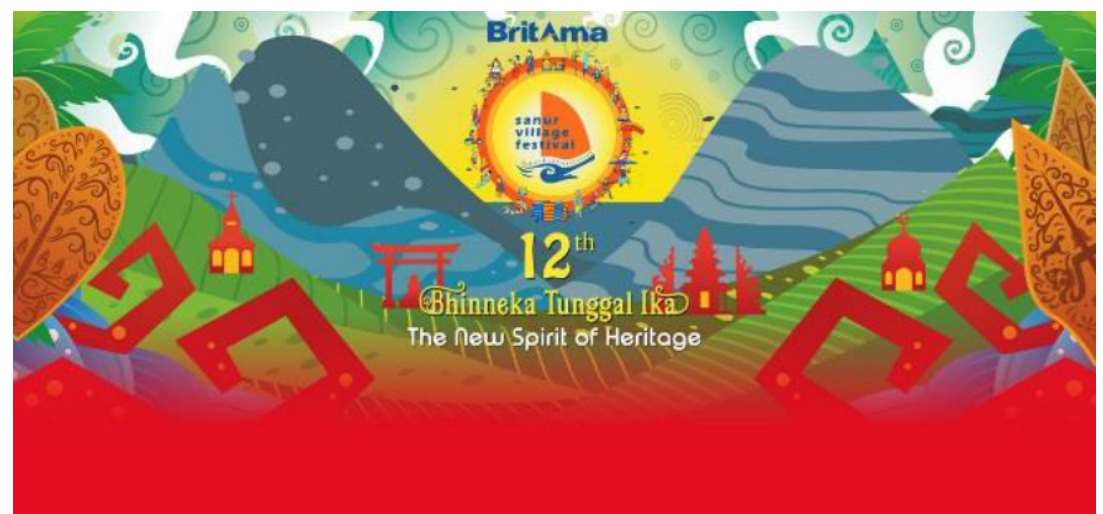

Figure 1 Bhinneka Tunggal Ika; the spirit of unity in diversity as its theme ${ }^{4}$

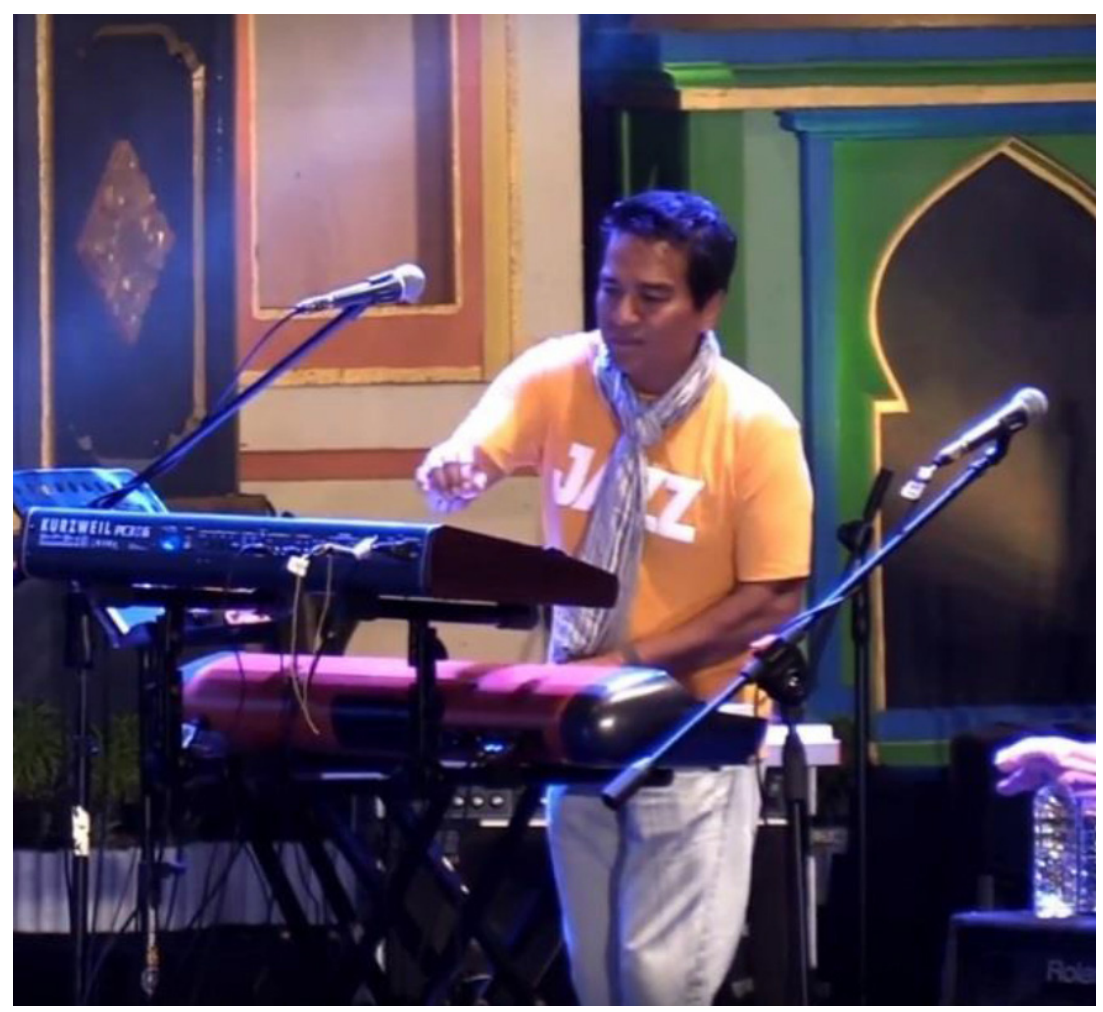

Figure 2 Indra Lesmana, as the main musicians on the main stage ${ }^{6}$

October 2017. The triathlon is a competition that combines three athletic sports namely swimming, running and international bikes. Events that have earned various awards including 'Best Destination Triathlon' will Held at Pantai Mertasari, Sanur.

\section{IMPACT ON SANUR'S SOCIETY}

In a press conference of BritAma SVF 2017 which was attended by Head of Tourism Department of Denpasar, Anak Agung Bagus Sudarsana, General Chairman of BritAma SVF, Ida Bagus Gede Sidharta Putra and BRI Regional Vice President Bali-Nusra, Yoyok Mulawarman at Maya Sanur Resort, on Monday (7/8/2017), it is known that SVF fosters synergy among communities of citizens, governments and state-owned enterprises (BUMN) to encourage productivity of creative economy and stimulate creativity of young talents. In addition to the promotion of destinations. According to Sidharta Putra, the festival that has entered its 12thyear celebration has embraced the creative economy to showcase their various ideas and products in the show, exhibition, workshop and dozens of activities during the festival. Also, there are young talents who participate enliven the festival that every day attract thousands of visitors.

To maintain the existence and quality of this event, Sidharta Putra always involves experienced figures to perform. For instance, in cultural arts performances, the committee always invites senior artists to determine which groups can play. "For music, we are assisted by Indra Lesmana as the main musicians on the main stage,"(Figure 2) he said.

In addition to curation, there is also regeneration for the performer as well as research market trends, thus what is performed is enjoyable by visitors. Sidharta Putra who is also Chairman of the Regional Tourism Promotion Board (BPPD) Denpasar said SVF has managed to create "repeater guests." This is proved by a number of hotel reservations and re-scheduling tourist arrivals in same time as SVF. Meanwhile, BRI Regional Vice President of Bali-Nusra Yoyok Mulawarman said BRI has been supporting SVF since 2010 and this time wants to optimize non-cash transaction services. "All transactions in the festival arena are only done by cashless transaction using digital cards or electronic money," he said. Visitors who use the Brizzi Card's electronic money will get various bonuses and rewards. Yoyok said fabulous offers are also given to visitors who open savings BRI BritAma, e-banking registration, apply credit card and purchase of Brizzi cards.

In addition, Bank BRI is going to appoint 146 MSMEs (33 MSMEs of whom are BRI's assistants) through product exhibition in the event. "Through this festival, we hope to increase the 'fee-based income' and explore the potential of other businesses associated with SMEs,"

While the Denpasar City Government, budgeted some funds for the preparation of infrastructure and various purposes of this festival such as stage, public toilets, cleanliness and others.?

\section{LAST DAY OF SANUR VILLAGE FESTI- VAL 2017}

Sanur Village Festival (SVF) 2017 took place festively. The event was packed with about 100 thousand tourists, dominated by foreign tourists. 
Moreover, the Even is predicted to reach IDR 45 billion in transaction. In addition to a busy event, lodging around Sanur is also fully booked by travelers. ${ }^{8}$

The five-day Sanur Village Festival (SVF) 2017 that ran from August 9 to 13 managed to generate more than Rp 45 billion in monetary transactions in the surrounding area of Maisonette Area Inna Grand Bali Beach, the festival's venue.

Sanur Village Festival committee head, Ida Bagus Gede Sidharta said "The economic impact is huge, all food and beverages stalls were always crowded with people, and everyone was shopping. Throughout the five days, there were about 100,000 tourists who came to SVF, if people spent IDR 500,000 (\$50), thus the total spending could reach billions of Rupiah, around IDR 45 billion," Ida added. The number IDR 500,000 is a minimum spending for a tourist. International visitors usually may spend up to IDR 850,000 per person.

Tourism Ministry's Archipelago Marketing Development deputy Esthy Reko Astuti said that the event attracted plenty of tourists from Europe. ${ }^{9}$ while Tourism Minister Arief Yahya said Sanur is an example of tourism development with communitybased and highly successful. One of them is the management of Sanur Market that he visited. According to Arief, this event could be imitated by other areas in developing tourism destinations with similar models. In his statement, he mentioned that every international event has two positive impacts on national tourism. There is direct impact or direct influence over the event, such as tourists who directly spend money on location. While indirect effect. Usually potential repeaters and media value. The success of an event informed by the press is a powerful means of promotion. ${ }^{8}$

\section{CONCLUSION}

Sanur village festival is community event involving a combination of several large-scale activities such as; food festival, creative economy exhibition, various contests and competitions, art and cultural attractions, music as well as various types of environmentally-friendly activities that successfully attract tourists to come every year since 2006. The event slowly turns into international event that always anticipated by tourists both local and international. it is proved by lodges around Sanur flocked by visitors on the date the event is being held. Tourism Minister, Arief Yahya said Sanur is an example of tourism development with community-based and highly successful. According to him, this event could be imitated by other areas in developing tourism destinations with similar models. International event has two positive impacts on national tourism. There is direct impact or direct influence over the event, such as tourists who directly spend money on location. While indirect effect. Usually potential repeaters and media value. The success of an event informed by the press is a powerful means of promotion, especially for tourism promotion.

\section{REFERENCES:}

1. Widyaswara, IWE. 2016. Makna Kata 'Sanur' Menurut Rai Mantra.Tribun Bali.http://bali.tribunnews.com/2016/06/ 02/makna-kata-sanur-menurut-rai-mantra

2. Official website of Sanur Village Festival.http://www. sanurvillagefestival.c om/about/

3. Anonymous. 2017. Sanur Village Festival 2017 to feature 27 activities. The Jakarta Post. http://www.thejakartapost. com/travel/2 017/08/05/sanur-village-festival-2017-tofeature-27-activities.html

4. http://www.sanurvillagefestival.com/

5. Anonymous. 2017. Sanur Village Festival 2017 Bertabur Agenda. CNN Indonesia. https://www.cnnindonesia.com/ gaya-hidup/20170805144345-307-232668/sanur-villagefestival-2017-bertabur-agenda/

6. Anonymous. 2017. Screenshot captured from Video 'Mostly Jazz All Stars ft. Tompi - Selalu Denganmu @ Sanur Village Festival 2017[HD]'YYoutubeChannel: MostlyJazzJKT. https://www.youtube.com/watch?v=x1CO1Mf83xA

7. Anonymous. 2017. BritAma Sanur Village Festival 2017 Dorong Produktivitas Pelaku Ekonomi Kreatif. Tribun News. http://www.tribunnews.com/bisnis/2017 /08/08/ britama-sanur-village-festival-2017-dorong-produktivitaspelakekonomi-kreatif

8. Anonymous. 2017. Pergelaran Sanur Village Festival Berlangsung Sukses. CNN Indonesia. h t t p s : / / w w w. c n n ind onesia.com/ga y hidup/20170815152112-307-234907/pergelaran-sanurvillage-festival-berlangsung-sukses/

9. Anonymous. 2017. Sanur Village Festival 2017 generates billions of income. The Jakarta Post. http://www. thejakartapost.com/travel/2 017/08/15/sanur-villagefestival-2017-generates-billions-of-income.html

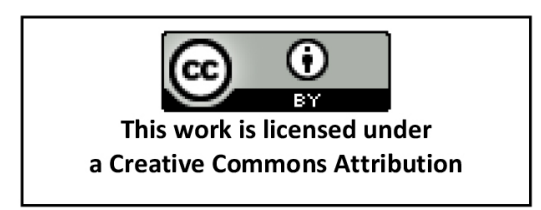

